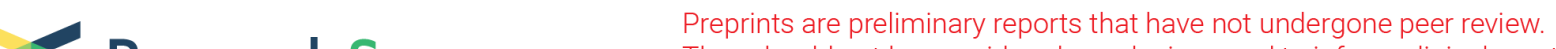 $\begin{array}{ll}\text { Research Square } & \begin{array}{l}\text { They should not be considered conclusive, used to inform clinical practice, } \\ \text { or referenced by the media as validated information. }\end{array}\end{array}$
}

\section{Geographic distance and vegetation structure rather than river barrier drive ant beta diversity across Central Amazonia}

Diego Rodrigues Guilherme ( $\nabla$ dguilherme14@gmail.com )

National Institute of Amazonian Research: Instituto Nacional de Pesquisas da Amazonia https://orcid.org/0000-0002-0310-9226

Pedro Aurélio Costa Lima Pequeno

UFRR - Campus Paricarana: Universidade Federal de Roraima

\section{Fabrício Beggiato Baccaro}

Federal University of Amazonas: Universidade Federal do Amazonas

\section{Elizabeth Franklin}

National Institute of Amazonian Research: Instituto Nacional de Pesquisas da Amazonia

Cláudio Rabelo dos Santos Neto

Federal University of Amazonas: Universidade Federal do Amazonas

Jorge Luiz Pereira de Souza

National Institute of Atlantic Forest: Instituto Nacional da Mata Atlantica

\section{Research Article}

Keywords: Amazon River, composition dissimilarity, dispersal limitation, natural selection, pitfall.

Posted Date: May 3rd, 2021

DOI: https://doi.org/10.21203/rs.3.rs-372225/v1

License: (1) (1) This work is licensed under a Creative Commons Attribution 4.0 International License. Read Full License 


\section{Abstract}

To understand better the effects of niche and neutral processes is important to disentangle the direct and indirect effects of each process, mainly if the environmental factors are geographically structured neglecting important indirect and synergic effects. We sampled ground-dwelling ant species on 126 plots distributed across eight sampling sites along a broad environmental gradient in Central Amazonia. Structural equation modelling was employed to quantify direct and indirect effects of geographic distance, the Amazon River's opposite margins, and environmental differences in temperature, precipitation and vegetation structure (Normalized Difference Vegetation Index) on ant beta diversity (Jaccard's dissimilarity). We found that geographic distance and NDVI differences had major direct effects on ant beta diversity. The major effect of temperature was indirect through NDVl, whereas precipitation had no detectable effect on beta diversity. The Amazon River had a weak influence on the ant composition dissimilarity. Our results challenge the major role often ascribed to riverine barriers in the diversification and distribution of Amazonian biota. Rather, ant compositional dissimilarity seems to be mainly driven by a combination of dispersal limitation and selection imposed by vegetation features and, indirectly, by temperature. We suggest that as NDVI differences decrease with geographic distance in the region, isolation by distance may have favoured phenotypic convergence between ant communities in the northern and southern borders of the Amazon Basin.

\section{Introduction}

Four higher-level processes can account for species compositional dissimilarity across sites: natural selection, ecological drift, dispersal and speciation (Vellend 2016). Selection arises due to (mis)matches between species requirements (i.e. their niche) and the environment. Accordingly, habitat conditions and resource availability can often explain assemblage species composition (Cottenie 2005). Species composition can also be driven by neutral or niche-independent processes, such as drift (random variation in births and deaths rates) and dispersal (species movement between sites) (Hubbell 2001; Cadotte 2006). For instance, geographic isolation associated with geographical barriers can prevent gene flow between populations, leading to speciation and contributing to assemblage dissimilarity (Oliveira et al. 2017; Boubli et al. 2015). However, niche and neutral processes are not mutually exclusive and the relative contributions of each process remain controversial (Matthews and Whittaker 2014). Importantly, most studies focus only on the direct effects of both processes, neglecting the structure of correlations between environmental and geographic factors and their indirect effects in generating patterns of diversity on larger scales.

Amazonia is the largest tropical forest remnant and a major cradle of biodiversity, being the source of much of the phylogenetic diversity spread over the Americas (Antonelli et al. 2018). Although the wide environmental variation of the region may explain part of the distribution of Amazonian biota (Ter Steege et al. 2006; Zuquim et al. 2014; Silva et al. 2019), large Amazonian rivers are thought to work as geographical barriers that preclude vertebrate dispersal (Cracraft 1985). For monkeys and understory birds, large rivers may foster allopatric speciation, resulting in compositional dissimilarity among 
interfluves (Ribas et al. 2012; Boubli et al. 2015; Oliveira et al. 2017). Further, the Amazon River seemingly has a stronger role among the large rivers due to its massive size and possibly ancient formation (Oliveira et al. 2017; Ruokolainen et al. 2019; Fluck et al. 2020).

Despite recent developments, Amazonian biogeography is still strongly biased towards macroscopic organisms, particularly vertebrates (Ribas et al. 2012; Leite and Rogers 2013; Antonelli et al. 2018) and plants (Kristiansen et al. 2012; Zuquim et al. 2014; Tuomisto et al. 2019). This gap is important because most known species are small-bodied invertebrates, such as insects and arachnids, which may respond differently to selective or neutral process. These animals often reach very high population densities and can disperse for long distances both actively and passively (e.g. through the wind, over the water or attached to larger animals) (Kaspari et al. 2010; Yamane 2013; Hakala et al. 2019).Thus, environmental selection might be more important than ecological drift and dispersal limitation in driving their biogeographic patterns. Furthermore, recent studies suggest that large Amazonian rivers are not substantial dispersal barriers to several insect taxa (Dambros et al. 2017; Santorelli et al. 2018; Dambros et al. 2020;). Therefore, a major gap in Amazonian biogeography is whether the current understanding of larger animals and plant distribution patterns applies to most of its biodiversity, which is small-bodied.

Ants are a highly diverse, abundant and ecologically relevant group (Folgarait 1998; Baccaro et al. 2015). Ants comprise $25 \%$ of the terrestrial animal biomass in tropical forests (Agosti et al. 2000), performing many roles in the ecosystem such as seed dispersers (Ness et al. 2004), regulating other arthropod populations (Tarli et al. 2014; Dambros et al. 2016) and incorporation of organic material in the soil. Studies in Amazonia have shown that geographic distance can account for invertebrate beta diversity, including ants (Dambros et al. 2017, 2020), although climate and vegetation are also known to correlate with ant distribution in the region (Vasconcelos et al. 2010; Guilherme et al. 2019). However, environmental variables such as climate and vegetation are geographically structured, resulting in important indirect and synergistic effects (Jiménez-Alfaro et al. 2016; Hurtado et al. 2019). For instance, geography can affect climate that may affect communities both directly and indirectly, through vegetation. Also, if selective environmental pressures are geographically structured, isolation by distance and by the environment may reinforce each other, possibly facilitating speciation over entire communities (Wang and Bradburd 2014). Despite this, the important distinction between direct and indirect effects in ecological systems (Shipley 2016) has been largely neglected by biogeographic studies, which typically assume direct effects only, e.g. in standard variance partitioning analyses (Tuomisto et al. 2003; Vasconcelos et al. 2010; Fluck et al. 2020).

In the present study, we used structural equation modelling to disentangle and quantify direct and indirect effects of geography (geographic isolation, margin of the Amazon River) and environment (temperature, precipitation and Normalized Difference Vegetation Index, NDVI) on the beta diversity of ground-dwelling ants across a latitudinal gradient in Central Amazonia. We hypothesized that: (i) due to the large habitat heterogeneity across the studied spatial extent and potential for long-distance dispersal, ant beta diversity should be more directly shaped by environmental selection (i.e. differences in climate and NDVI) than by dispersal limitation (i.e. geographic distance and difference and river margin); and (ii) due to the 
geographic structure of climate and the latter's effect on vegetation, we expected geographic distance to have mainly an indirect effect on ant beta diversity.

\section{Material And Methods}

\section{Study sites}

The ground-dwelling ants were collected in eight sampling sites maintained by the Brazilian Biodiversity Research Program; in Portuguese: Programa de Pesquisas em Biodiversidade, PPBio (Costa and Magnusson 2010). The sites are located in the Brazilian Amazon Forest, covering the geographical extent of approximately $1,050 \mathrm{~km}$ (between the first and last sampling point, in the North/South direction). The study area covers a precipitation gradient of $\sim 1700 \mathrm{~mm}$ in the northern sites, to $\sim 2400 \mathrm{~mm}$ in the central and southern sites. The vegetation type is mostly characterized as dense ombrophylous forest. It also includes other vegetation such as savannas and white-sand vegetation with a small area subject to flooding in the rainy season (Instituto Brasileiro de Geografia e Estatística - IBGE 2012) (Table 1). 
Table 1

Sampling sites, geographic coordinates, vegetation types, range of NDVI, and precipitation and temperature averages at each sampling site.

\begin{tabular}{|c|c|c|c|c|c|}
\hline Sites & Coordinates & Vegetation Types & $\begin{array}{l}\text { Range } \\
\text { NDVI } \\
\text { Index }\end{array}$ & $\begin{array}{l}\text { Average } \\
\text { precipitation }\end{array}$ & $\begin{array}{l}\text { Average } \\
\text { temperature }\end{array}$ \\
\hline Maracá & $\begin{array}{l}\text { Longitude } \\
-61.473 \\
\text { Latitude } \\
3.396\end{array}$ & $\begin{array}{l}\text { Open ombrophylous forest, } \\
\text { Semideciduous forest, } \\
\text { Deciduous forest, } \\
\text { Campinarana forest }\end{array}$ & $\begin{array}{l}0.44- \\
0.62\end{array}$ & $1988 \mathrm{~mm}$ & $26.74 \mathrm{C}^{\circ}$ \\
\hline Cauamé & $\begin{array}{l}\text { Longitude } \\
-60.715 \\
\text { Latitude } \\
2.883\end{array}$ & Open savana & $\begin{array}{l}0.05- \\
0.18\end{array}$ & $1764 \mathrm{~mm}$ & $27.98 \mathrm{C}^{\circ}$ \\
\hline Viruá & $\begin{array}{l}\text { Longitude } \\
-61.006 \\
\text { Latitude } \\
1.441\end{array}$ & $\begin{array}{l}\text { Open ombrophylous forest, } \\
\text { Campinarana forest } \\
\text { Seasonal campinarana, } \\
\text { Seasonal shrubby } \\
\text { campinarana }\end{array}$ & $\begin{array}{l}0.25- \\
0.65\end{array}$ & $1897 \mathrm{~mm}$ & $27.27 \mathrm{C}^{\circ}$ \\
\hline Ducke & $\begin{array}{l}\text { Longitude } \\
-59.942 \\
\text { Latitude - } \\
2.950\end{array}$ & Dense ombrophylous forest & $\begin{array}{l}0.57- \\
0.66\end{array}$ & $2300 \mathrm{~mm}$ & $26.47 \mathrm{C}^{\circ}$ \\
\hline Manaquiri & $\begin{array}{l}\text { Longitude } \\
-60.308 \\
\text { Latitude } \\
-3.673\end{array}$ & Open ombrophylous forest & $\begin{array}{l}0.60- \\
0.64\end{array}$ & $2218 \mathrm{~mm}$ & $26.74 \mathrm{C}^{\circ}$ \\
\hline Orquestra & $\begin{array}{l}\text { Longitude } \\
-61.555 \\
\text { Latitude - } \\
4.994\end{array}$ & Dense ombrophylous forest & $\begin{array}{l}0.56- \\
0.60\end{array}$ & $2444 \mathrm{~mm}$ & $26.91 \mathrm{C}^{\circ}$ \\
\hline Capana & $\begin{array}{l}\text { Longitude } \\
-62.193 \\
\text { Latitude - } \\
5.629\end{array}$ & Dense ombrophylous forest & $\begin{array}{l}0.57- \\
0.61\end{array}$ & $2184 \mathrm{~mm}$ & $26.74 \mathrm{C}^{\circ}$ \\
\hline Jari & $\begin{array}{l}\text { Longitude } \\
-62.504 \\
\text { Latitude- } \\
5.953\end{array}$ & Dense ombrophylous forest & $\begin{array}{l}0.59- \\
0.61\end{array}$ & $2136 \mathrm{~mm}$ & $26.57 \mathrm{C}^{\circ}$ \\
\hline
\end{tabular}


The sampled sites also cover a large variety of soil types (Quesada et al. 2011). Four sites are in the Guiana Shield, at the north of the Amazon River. This region has a greater predominance of Acrisols and Ferralsols. The other four sites are located south of the Amazon River, in the interfluve between the Purus and Madeira rivers. These sites have a predominance of Plinthosols soils, forming part of the Brazilian Shield (Quesada et al. 2011). The location of collection sites and the position of the Amazon River are shown in Fig. 1.

\section{Experimental design and ant sampling}

We used the RAPELD sampling design to sample ants (Magnusson et al. 2013). Each collection site gives access to permanent plots where several organisms and environmental variables have been surveyed (Costa and Magnusson 2010). The sampling sites are structured by a grid-shaped system with 30 plots, and modules with five or ten plots, totalizing 126 plots in the whole study area. Each grid has six parallel trails of $5 \mathrm{~km}$ located $1 \mathrm{~km}$ apart with five permanent plots distributed at least $1 \mathrm{~km}$ apart along each trail. Each module has one or two trails following the same sampling design of the grids. The plot is $250-\mathrm{m}$ long and 1-m wide, following the altitudinal contours to minimize within-plot environmental variation (Magnusson et al. 2013). Plot geographic position was measured with a GPS (Global Position System) using the reference system datum WGS84. Geographic coordinates were obtained at the central part of the plots.

Ants were collected between September 2006 and June 2012, and all collections were carried out in the respective dry season. Ants were sampled with pitfall traps (plastic cups $8 \mathrm{~cm}$ long by $9.5 \mathrm{~cm}$ in diameter), placed at $25 \mathrm{~m}$ intervals, totalling ten traps per plot. Overall 1260 pitfalls were deployed. Pitfalls were buried until their edge remained at the same level as the ground and filled with $1 / 3$ of $70 \%$ alcohol and a few detergent drops. After $48 \mathrm{~h}$ the traps were collected. All ants were sorted and stored in $90 \%$ alcohol (Souza et al. 2016). Ants were identified up to genus level using taxonomic keys (Baccaro et al. 2015), morphotyped, and when possible, identified to species level using available taxonomic keys or by specialists and by comparison with specimens deposited in zoological collections (https://ppbio.inpa.gov.br). Voucher specimens were deposited at INPA's Invertebrate Collection.

\section{Environmental data}

To evaluate how the environment may influence ant species compositional dissimilarity between plots, we extracted information on climate and vegetation. Climate information was collected from the bioclimatic variables of WorldClim version 2 (Fick and Hijmans 2017). We used average annual precipitation and temperature to represent major climatic gradients, as they have clear biological meanings as availability of energy and water, respectively, strongly correlate with other bioclimatic variables (Appendix Supplementary), and have been shown to affect ant species composition (Vasconcelos et al. 2010; Ramos et al. 2018). The data were downloaded at a spatial resolution of 30 seconds $\left(\sim 1 \mathrm{~km}^{2}\right)$.

Vegetation structure was estimated using the Normalized Difference Vegetation Index (NDVI). NDVI is a measure that summarizes many factors that affect an ant's life, such as primary productivity and habitat 
complexity (Kaspari et al. 2000; Bailey et al. 2004; Pettorelli et al. 2005). To obtain NDVI data, images from the Landsat 4-5 Thematic Mapper (TM) satellite were extracted from the United States Geological Survey-USGS website. The images obtained had pixels with a spatial resolution of $30 \mathrm{~m}\left(\sim 900 \mathrm{~m}^{2}\right)$ and were related to each location's collection period (month/year). Images with less cloud coverage were selected within each collection (month/year) in each location to avoid cloud coverage interference in obtaining the NDVI values, NDVI values were extracted from each pixel where the plots were present.

\section{Data analysis}

We first applied the multi-site Jaccard dissimilarity index to species presence-absence data to measure overall ant beta diversity among plots. Since beta diversity has different components, we decomposed the overall beta diversity $\left(\beta_{\mathrm{jac}}\right)$ into its turnover $\left(\beta_{\mathrm{jtu}}\right)$ and nestedness components $\left(\beta_{\mathrm{jne}}\right)$ (Baselga 2010). As the overall beta diversity almost totally consisted of turnover $\left(\beta_{\mathrm{jtu}}=0.986 ; \beta_{\mathrm{jne}}=0.003\right)$ we used the undecomposed, pairwise Jaccard dissimilarities to represent between-plot beta diversity in the analysis.

The predictors of beta diversity were three environmental Euclidean distances (difference in average annual precipitation, difference in average annual temperature, and difference in NDVI), geographic distance, and riverbank (whether plots were at the same or opposite riverbanks, coded as a dummy variable), all computed for each pair of plots. Then, to investigate expected causal relationships among these variables, we applied Structural Equation Modelling (SEM) (Shipley 2016). SEM consists of building a set of linear models (Table 2) representing the hypothesized relationships in a path diagram (Fig. 2), which in the current case were estimated with multiple regressions on distance matrices (MRM) (Lichstein 2007).

Table 2

Linear models used to build the Structural Equation Model on ants beta diversity. A.R.: Amazon River, G.D.: Geographic distance, T.D.: Temperature Difference, P.D.: Precipitation Difference and NDVI: NDVI Difference.

\begin{tabular}{llll}
\hline \multicolumn{3}{l}{ Models of causal hypothetical relationships in path diagram } & \multicolumn{1}{l}{ References } \\
\hline Ants $\sim$ A.R. + G.D. + T.D. + P.D. + NDVI & $\begin{array}{l}\text { Wepfer et al. 2016; Lassau et al. } \\
2005\end{array}$ \\
\hline NDVI $\sim$ A.R. + G.D. + T.D. + P.D. & Sun and Qin 2016 \\
\hline P.D. $\sim$ T.D. + G.D. & & Lochbihler et al. 2017 \\
\hline T.D. $\sim$ G.D. & & Almeida et al. 2017
\end{tabular}

Notes: All predictors were log-transformed, except Amazon River bank

Based on the literature, we built the path diagram including hypothesized direct effects of both environment (temperature, precipitation, and NDVI) and geography (distance and riverbank) on ant dissimilarity and indirect effects of geography on dissimilarity through the environment (Fig. 2). We also included indirect effects of climate (temperature and precipitation) and riverbank on dissimilarity through 
their putative effects on vegetation (NDVI) (Fig. 2). All predictors except riverbank were log-transformed to account for curvilinear relationships, and predictor effects were tested with permutation tests (999 permutations). Overall structural model fit was tested using Fisher's $C$ statistic, under the null hypothesis that the data were consistent with the hypothetical relationships, i.e. there was weak support to nonexpected relationships in the path diagram $(P>0.05)$ (Lefcheck 2016).

All statistical analyses were performed in the R environment for statistical computing ( $R$ Core team 2020; version 4.0.1) with support of packages "vegan" (Oksanen et al. 2020), "ecodist" (Goslee and Urban 2007), "visreg” (Breheny and Burchett 2020), "adespatial" (Dray et al. 2021), "ade4" (Dray et al. 2020), "betapart" (Baselga et al. 2020) and "piecewiseSEM" (Lefcheck et al. 2020).

\section{Results}

Over the 126 plots, we sampled 326 species/morphospecies of ants. The number of ant species per plot varied from 2 to 56 species. The most frequent species was Pachycondyla crassinoda (Latreille, 1802) occurring in $73 \%$ (92) plots of the sampling sites. On the other extreme, more than $1 / 3$ of the species were sampled once (73 species) or twice (40 species).

Our sampling plots encompassed open ("savanna-like") areas, open forests and dense forests covering the large environmental heterogeneity typical of the Central Amazon. While the study area has little variation in the range of temperature $\left(\right.$ minimum $=26.35 \mathrm{C}^{\circ}$; maximum $\left.=28.04 \mathrm{C}^{\circ}\right)$, variation in annual precipitation (minimum $=1737 \mathrm{~mm}$; maximum $=2449 \mathrm{~mm}$ ) and NDVI (index minimum $=0.05$; maximum $=0.66)$ are much higher.

The SEM showed that the hypothesized relationship between geographic distance and barrier, environmental variables, and ant compositional dissimilarity provided a consistent description of the data (Fisher's $C$ test $=2.30, P=0.32$ ). The standardized coefficients indicated that geographic distance indirectly affected the ants through vegetation and temperature, and its direct effect upon ant composition dissimilarity was slightly greater than that of NDVI and stronger than other direct effects (Fig. 3). Temperature had an indirect effect on ant composition through NDVI, with NDVI showing the strongest direct effect among environmental predictors on ant beta diversity (Fig. 3). The Amazon River had a relatively weak influence on ant distribution and precipitation did not affect ant species dissimilarity directly or indirectly (Fig. 3). The overall model explained $52 \%$ of the variation of ant composition dissimilarity across our 126 plots (Fig. 4).

\section{Discussion}

Our results highlight how the beta diversity of ground-dwelling ants is structured across the Amazon Basin through dispersal limitation (geographic distance and Amazon River) and environmental selection (NDVI and temperature). Remarkably, ant beta diversity was more strongly related to geographic distance and environmental variables than to a major, putative geographic barrier (the Amazon River). This finding is in accordance with the most recent evidence on the limited role of large rivers on Amazonian species 
distributions (Dambros et al. 2017; Oliveira et al. 2017; Fluck et al. 2020; Dambros et al. 2020), and partially supports our hypothesis that selection along environmental gradients is the major driver of biogeographic patterns in smaller-bodied, shorter-lived animals such as ants. However, the results showed that geographic distance has a relatively strong, independent direct effect on ant species dissimilarity, suggesting that neutral processes equally relevant to the distribution and diversification of Amazonian ants.

We hypothesized that climate would affect directly and strongly ant species dissimilarity. Temperature affects ant thermoregulation, shaping thermal niches (Cerdá et al. 1998; Cerdá and Retana 2000; Kaspari et al. 2019) and also is related to species richness at larger scales (Dunn et al. 2009). Indeed, we found that temperature had a direct effect on compositional dissimilarity, corroborating that even the low variation in temperature of the Amazon may affect the physiology of soil arthropods (Pequeno et al. 2020). Nevertheless, temperature's greatest effect was indirect, through NDVI ( $b$ indirect $=0.74 \times 0.36=$ 0.27 vs. $b$ direct $=0.17$ ), which had the strongest direct effect among environmental variables (Fig. 3 ). Relationships between temperature and primary productivity (which is incorporated in NDVI) are known to affect ant distribution (Kaspari et al. 2000; Kaspari et al. 2004). For instance, temperature limits primary productivity, and productivity limits the abundance of consumer taxa, cascading to higher trophic levels (Kaspari et al. 2004). Our results extend this idea by showing that the combination of temperature and NDVI are also important factors influencing ant beta diversity. Indeed, the total effect of temperature had the same magnitude as the strongest direct effect, attributed to geographic distance (i.e. sum of direct and indirect effects, $b$ total $=0.74 \times 0.36+0.17=0.43)$.

NDVI integrates vegetation structure, plant species composition and productivity in a single measure, and any of these features could contribute directly to ant species turnover. For instance, habitat complexity is known to structure ant communities by filtering species based on their morphology (Kaspari and Weiser 1999; Wiescher et al. 2012; Gibb and Parr 2013; Guilherme et al. 2019; Nooten et al. 2019). Therefore, dissimilarity in species composition can reflect differences in ant morphological composition, consistent with relationships between mean community traits and habitat complexity shown for ants in the same region (Guilherme et al. 2019). Given that our sampling sites covered different vegetation types (e.g. from open savannas to dense forests), NDVI may also reflect a change in plant species composition or plantbased structure provision (litter structure), which may affect some ground-dwelling ant species (Donoso et al. 2010). An interesting venue for research is to understand how these different facets of vegetation are related to NDVI measures, and which variable is more related with ant species turnover.

Contrary to our hypothesis, precipitation had no direct or indirect effect after accounting for other predictors. This result is surprising given the expected role of precipitation at local and regional scales. It is possible that precipitation interacts with topography and, thus, affects ant species composition mainly in lowlands, due to disturbance caused by water percolation (Oliveira et al. 2009; Baccaro et al. 2013), or unpredictable flooding (Mertl et al. 2009). Vasconcelos et al. (2010) noted a change in ant species composition along a longitudinal (rather than latitudinal) precipitation gradient (ranging from $~ 1600$ to $\sim 3100 \mathrm{~mm}$ ) in the Amazon, with marked changes in precipitation between periodic flooded vs. unflooded 
forests. In fact, flooding may have strong effect on ant taxonomic and functional diversity (Majer and Delabie 1994; Pringle et al. 2019). It is possible that the relatively narrow precipitation gradient (ranging between 1737 and $2449 \mathrm{~mm}$ ), associated with the relatively few plots subject to flooding investigated here, may have lowered the relative importance of precipitation.

The independent effect of geographic distance on species dissimilarity is consistent with dispersal limitation. Although we predicted a mostly indirect effect via environmental predictors, the relatively strong direct effect reported here is in accordance with recent data on some invertebrates, including termites and ants (Dambros et al. 2017, 2020). The curvilinear relationship shows that the major difference in dissimilarity occurs along the first 200 kilometres, remaining approximately constant afterward. Although studies about the dispersal distance of ants are scant (Helms 2018) this pattern is expected from the average dispersal kernel of organisms, e.g. a fat-tailed distribution, where many individuals are dispersing over short distances and few individuals dispersing over long distances (Hubbell 2001). This dispersal kernel pattern may also be related to the colony founding process, where some species are more restricted to nearby locations (dependent founding or nest-budding). In contrast, other species may have the ability to fly over long distances (independent founding) (Keller and Passera 1989) or be carried over, e.g. by rafting through major rivers (see below). In both cases, finding a good habitat for a new colony foundation is an essential part of successful ant dispersal (Helms 2018; Hakala et al. 2019). It is possible that selection may negatively affect long distance dispersal through the correlation between geographic distance and temperature difference, albeit it was weak (Fig. 3). In contrast, the correlation between geographic distance and NDVI difference was negative, so that farther sites had more similar vegetation (Fig. 3), which could actually facilitate long distance dispersal.

The correlation between geographic and environmental distances may couple genetic isolation along these gradients, thus reinforcing population divergence and speciation over time (Wang and Bradburd 2014). Yet, our analysis revealed that the strongest effect of geographic distance on environmental distance related to temperature, which only had a weak direct effect on compositional dissimilarity (Fig. 3). However, the negative relationship between NDVI difference and geographic distance implies that farther sites should select similar phenotypes by having similar vegetation. Therefore, there may have been phenotypic convergence between the Amazon Basin's northern and southern borders over time, which is consistent with the trait-vegetation relationships observed for ants across the region (Guilherme et al. 2019).

The riverine barrier hypothesis has been an influential idea in Amazonian biogeography, with several studies investigating Amazonian rivers' effect on species distribution and diversification (Wallace 1854; Cracraft 1985; Ribas et al. 2012; Boubli et al. 2015; Oliveira et al. 2017). However, based on species distribution patterns, there is increasing evidence that the river barrier effect may have been overestimated and that other factors may be more important to many taxa, especially smaller-bodied arthropods (Dambros et al. 2017; Santorelli et al. 2018; Silva et al. 2019; Fluck et al. 2020; Dambros et al. 2020). More studies focused on the evolutionary process (Ribas et al. 2012; Boubli et al. 2015; Alfaro et al. 2015; Ruokolainen et al. 2019) are needed to properly address this hypothesis, as the number of 
cryptic species among invertebrates is usually high (Ross et al. 2010; Rosser et al. 2019: SánchezRestrepo et al. 2020). Cryptic species can underestimate the role of riverine barriers, but only if morphologically indistinguishable species occupy opposite river banks (Fernandes et al. 2013). The Amazon River is the most ancient between current large Amazonian rivers (Ruokolainen et al. 2019) and, therefore, the most likely to have produced allopatric speciation. As the Amazon River had a weak effect upon ant beta diversity, other tributaries are unlikely to be effective obstacles to most ant species. Furthermore, some ant species have been recorded dispersing through rafting in dead wood or through wind currents (Yamane 2013). Therefore, large Amazonian rivers may function as corridors for longdistance dispersal rather than dispersal barriers, although other factors may hamper long-distance dispersal success (e.g. colony foundation).

This study suggests that ant species dissimilarity across Central Amazonia is driven by a balanced combination of dispersal limitation and environmental selection. By explicitly measuring direct and indirect effects, we were able to show that climate (temperature and precipitation) and one major riverine barrier had secondary roles relative to spatial distance and vegetation structure. The extent to which dispersal and selection has contributed not only to contemporary distribution patterns but also to ant speciation remains an open question. Our results suggest that the negative coupling between geographic distance and vegetation differences across central Amazonia have favoured phenotypic convergence between northernmost and southernmost ant faunas in the region.

\section{Declarations}

\section{ACKNOWLEDGMENTES}

We thank Daniel Ferreira for helping in the extraction of NDVI data. We also thank Bruna Mendel for constructive discussions about the measurements of geographic distance. D.R.G. was supported by CAPES scholarship doctoral and J.L.P.S. was supported by a CNPq PCI/INMA (302364/2020-0) postdoctoral scholarship.

FUNDING - This study was supported by the "Fundação de Amparo a Pesquisas do Estado do Amazonas (FAPEAM)" FIXAM/AM 062.01325/2014 and Universal Amazonas 62.00674/2015; "Coordenação de Aperfeiçoamento de Pessoal de Nível Superior (CAPES)" PNPD/03017/19-05; "Conselho Nacional de Desenvolvimento Científico e Tecnológico (CNPq)", PRONEX 16/2006 and

“Programa de Pesquisa em Biodiversidade (PPBio)" 558318/2009-6, 457545/2012-7.

CONFLICTS OF INTERESTS - The authors declare that they have no conflict of interest.

ETHICS APPROVAL - Ethics approval was not required for this study according to local legislation [law 11.794/08.10.2008 from Conselho Nacional de Controle de Experimentação Animal of Brazilian Government]. 
CONSENT TO PARTICIPATE - All patients included in this study gave written informed consent to participate in this research.

CONSENT TO PUBLISH - All patients provided written informed consent to publish the data contained within this article.

AVAILABILITY OF DATA AND MATERIALS - The datasets used and/or analysed during the current study are available from the corresponding author on reasonable request.

\section{References}

Agosti D, Majer JD, Alonso LE, Schultz TR (2000). Standard methods for measuring and monitoring biodiversity. 9 Ed., Smithsonian Institution, Washington $D C$

Antonelli A, Zizka A, Carvalho FA, Scharn R, Bacon CD, Silvestro D, Condamine FL (2018) Amazonia is the primary source of Neotropical biodiversity. Proc Natl Acad Sci U S A 115:6034-6039 .

https://doi.org/10.1073/pnas.1713819115

Arnan X, Cerdá X, Retana J (2014) Ant functional responses along environmental gradients. J Anim Ecol 83:1398-1408 . https://doi.org/10.1111/1365-2656.12227

Baccaro FB, Feitosa RM, Fernández F, Fernandes IO, Izzo TJ, Souza JLP, Solar, R. (2015). Guia para os gêneros de formigas do Brasil. Editora INPA, Manaus

Baccaro FB, Rocha IF, del Aguila BEG, Schietti J, Emilio T, Pinto JLP da V, Lima AP, Magnusson WE (2013) Changes in ground-dwelling ant functional diversity are correlated with water-table level in an amazonian terra firme forest. Biotropica 45:755-763 . https://doi.org/10.1111/btp.12055

Bailey SA, Horner-Devine MC, Luck G, Moore LA, Carney KM, Anderson S, Betrus C, Fleishman E (2004) Primary productivity and species richness: Relationships among functional guilds, residency groups and vagility classes at multiple spatial scales. Ecography (Cop) 27:207-217 . https://doi.org/10.1111/j.09067590.2004.03631.x

Baselga A (2010) Partitioning the turnover and nestedness components of beta diversity. Glob Ecol Biogeogr 19:134-143 . https://doi.org/10.1111/j.1466-8238.2009.00490.x

Baselga A, Orme D, Villeger S, Baselga MA (2020) Package ' betapart'

Boubli JP, Ribas C, Lynch Alfaro JW, Alfaro ME, da Silva MNF, Pinho GM, Farias IP (2015) Spatial and temporal patterns of diversification on the Amazon: A test of the riverine hypothesis for all diurnal primates of Rio Negro and Rio Branco in Brazil. Mol Phylogenet Evol 82:400-412 https://doi.org/10.1016/j.ympev.2014.09.005

Breheny P, Burchett W (2020) Package "visreg." R Packag version 270 
Cadotte MW (2006) Dispersal and species diversity: A meta-analysis. Am Nat 167:913-924 . https://doi.org/10.1086/504850

Costa FRC, Magnusson WE (2010) The Need for Large-Scale, Integrated Studies of Biodiversity - the Experience of the Program for Biodiversity Research in Brazilian Amazonia. 8:3-12 .

https://doi.org/10.4322/natcon.00801001

Cottenie K (2005) Integrating environmental and spatial processes in ecological community dynamics. Ecol Lett 8:1175-1182 . https://doi.org/10.1111/j.1461-0248.2005.00820.x

Cracraft J (1985) Historical Biogeography and Patterns of Differentiation within the South American Avifauna: Areas of Endemism. Ornithol Monogr 49-84 . https://doi.org/10.2307/40168278

Dambros C, Zuquim G, Moulatlet GM, Costa FRC, Tuomisto H, Ribas CC, Azevedo R, Baccaro F, Bobrowiec PED, Dias MS, Emilio T, Espirito-Santo HMV, Figueiredo FOG, Franklin E, Freitas C, Graça MB, d'Horta F, Leitão RP, Maximiano M, Mendonça FP, Menger J, Morais JW, de Souza AHN, Souza JLP, da C. Tavares V, do Vale JD, Venticinque EM, Zuanon J, Magnusson WE (2020) The role of environmental filtering, geographic distance and dispersal barriers in shaping the turnover of plant and animal species in Amazonia. Biodivers Conserv 29:3609-3634 . https://doi.org/10.1007/s10531-020-02040-3

Dambros CS, Morais JW, Azevedo RA, Gotelli NJ (2017) Isolation by distance, not rivers, control the distribution of termite species in the Amazonian rain forest. Ecography (Cop) 40:1242-1250 . https://doi.org/10.1111/ecog.02663

Dambros CS, Morais JW, Vasconcellos A, Souza JLP, Franklin E, Gotelli NJ (2016) Association of Ant Predators and Edaphic Conditions with Termite Diversity in an Amazonian Rain Forest. Biotropica 48:237-245 . https://doi.org/10.1111/btp.12270

Donoso DA, Johnston MK, Kaspari M (2010) Trees as templates for tropical litter arthropod diversity. Oecologia 164:201-211 . https://doi.org/10.1007/s00442-010-1607-3

Dray AS, Bauman D, Blanchet G, Borcard D, Clappe S, Guenard G, Jombart T, Larocque G, Legendre P, Madi N, Wagner HH (2021) Package ' adespatial .' https://doi.org/10.1890/11-1183.1 >.Maintainer

Dunn RR, Agosti D, Andersen AN, Arnan X, Bruhl CA, Cerdá X, Ellison AM, Fisher BL, Fitzpatrick MC, Gibb H, Gotelli NJ, Gove AD, Guenard B, Janda M, Kaspari M, Laurent EJ, Lessard JP, Longino JT, Majer JD, Menke SB, McGlynn TP, Parr CL, Philpott SM, Pfeiffer M, Retana J, Suarez A V., Vasconcelos HL, Weiser MD, Sanders NJ (2009) Climatic drivers of hemispheric asymmetry in global patterns of ant species richness. Ecol Lett 12:324-333 . https://doi.org/10.1111/j.1461-0248.2009.01291.x

Fernandes AM, Gonzalez J, Wink M, Aleixo A (2013) Multilocus phylogeography of the Wedge-billed Woodcreeper Glyphorynchus spirurus (Aves, Furnariidae) in lowland Amazonia: Widespread cryptic 
diversity and paraphyly reveal a complex diversification pattern. Mol Phylogenet Evol 66:270-282 . https://doi.org/10.1016/j.ympev.2012.09.033

Fick SE, Hijmans RJ (2017) WorldClim 2: new 1-km spatial resolution climate surfaces for global land areas. Int J Climatol 37:4302-4315 . https://doi.org/10.1002/joc.5086

Fluck IE, Cáceres N, Hendges CD, Brum M do N, Dambros CS (2020) Climate and geographic distance are more influential than rivers on the beta diversity of passerine birds in Amazonia. Ecography (Cop) 43:860-868 . https://doi.org/10.1111/ecog.04753

Gibb H, Parr CL (2013) Does Structural Complexity Determine the Morphology of Assemblages? An Experimental Test on Three Continents. PLoS One 8:1-7 . https://doi.org/10.1371/journal.pone.0064005

Goslee SC, Urban DL (2007) The ecodist package for dissimilarity-based analysis of ecological data Guilherme DR, Souza JLP, Franklin E, Pequeno PACL, Chagas AC das, Baccaro FB (2019) Can environmental complexity predict functional trait composition of ground-dwelling ant assemblages? A test across the Amazon Basin. Acta Oecologica 99:103434 .

https://doi.org/10.1016/J.ACTA0.2019.05.004

Hakala, Sanja Maria; Seppä, Perttu; Helanterä H (2019) Evolution of dispersal in ants (Hymeno ptera: Formicidae): a review on the dispersal strategies of sessile superorganisms. Myrmecological News 29:35-55 . https://doi.org/10.25849/myrmecol.news

Helms JA (2018) The flight ecology of ants (Hymenoptera: Formicidae). Myrmecological News 10:4136

Hubbell, SP (2001). The unified neutral theory of biodiversity and biogeography (Vol.32). Princeton University Press, Oxford

Hurtado P, Prieto M, Aragón G, Escudero A, Martínez I (2019) Critical predictors of functional, phylogenetic and taxonomic diversity are geographically structured in lichen epiphytic communities. J Ecol 107:23032316. https://doi.org/10.1111/1365-2745.13189

Instituto Brasileiro de Geografia e Estatística-IBGE, 2012. Manual Técnico da Vegetação Brasileira/Brazilian Vegetation Classification System 2a. Retrieved from. https:// biblioteca.ibge.gov.br/visualizacao/livros/liv63011.pdf.

Jiménez-Alfaro B, Chytrý M, Mucina L, Grace JB, Rejmánek M (2016) Disentangling vegetation diversity from climate-energy and habitat heterogeneity for explaining animal geographic patterns. Ecol Evol 6:1515-1526. https://doi.org/10.1002/ece3.1972

Jon A, Byrnes J, Grace J (2020) Package ' piecewiseSEM ' 
Kaspari M, Bujan J, Roeder KA, Beurs K de, Weiser MD (2019) Species energy and Thermal Performance Theory predict 20-yr changes in ant community abundance and richness. Ecology 100:1-7 . https://doi.org/10.1002/ecy.2888

Kaspari M, Chang C, Weaver J (2010) Salted roads and sodium limitation in a northern forest ant community. Ecol Entomol 35:543-548 . https://doi.org/10.1111/j.1365-2311.2010.01209.x

Kaspari M, Donnell S, Kercher JR (2000) Energy, density, and constraints to species richness: Ant assemblages along a productivity gradient. Am Nat 155:280-293 . https://doi.org/10.1086/303313

Kaspari M, Ward PS, Yuan M (2004) Energy gradients and the geographic distribution of local ant diversity. Oecologia 140:407-413 . https://doi.org/10.1007/s00442-004-1607-2

Kaspari M, Weiser MD (1999) The size - grain hyphotesis and Interespecific scaling in ants. Fuctional Ecol 13:530-538 . https://doi.org/jstor.org/stable/2656560

Keller L, Passera $L$ (1989) Size and fat content of gynes in relation to the mode of colony founding in ants (Hymenoptera; Formicidae). Oecologia 80:236-240 . https://doi.org/10.1007/BF00380157

Kristiansen T, Svenning JC, Eiserhardt WL, Pedersen D, Brix H, Munch Kristiansen S, Knadel M, Grández C, Balslev H (2012) Environment versus dispersal in the assembly of western Amazonian palm communities. J Biogeogr 39:1318-1332 . https://doi.org/10.1111/j.1365-2699.2012.02689.x

Lefcheck JS (2016) piecewiseSEM: Piecewise structural equation modelling in $r$ for ecology, evolution, and systematics. Methods Ecol Evol 7:573-579 . https://doi.org/10.1111/2041-210X.12512

Lichstein JW (2007) Multiple regression on distance matrices: A multivariate spatial analysis tool. Plant Ecol 188:117-131 . https://doi.org/10.1007/s11258-006-9126-3

Lynch Alfaro JW, Boubli JP, Paim FP, Ribas CC, Silva MNF d., Messias MR, Röhe F, Mercês MP, Silva Júnior JS, Silva CR, Pinho GM, Koshkarian G, Nguyen MTT, Harada ML, Rabelo RM, Queiroz HL, Alfaro ME, Farias IP (2015) Biogeography of squirrel monkeys (genus Saimiri): South-central Amazon origin and rapid pan-Amazonian diversification of a lowland primate. Mol Phylogenet Evol 82:436-454 . https://doi.org/10.1016/j.ympev.2014.09.004

Magnusson W, Braga-Neto R, Pezzini F, Baccaro FB, Penha HBJ, Rodrigues D, Verdade LM, Lima A, Albernaz AL, Hero J-M, Lawson B, Castilho C, Drucker D, Franklin E, Mendonça F, Costa F, Galdino G, Zuanon J, do Vale J, Santos JLC dos, Luizão R, Cintra R, Barbosa RI, Lisboa A, Koblitz RV, Cunha CN da, Pontes ARM (2013) Biodiversidade e Monitoramento Ambiental Integrado Átema editorial, São Paulo

Matthews TJ, Whittaker RJ (2014) Neutral theory and the species abundance distribution: Recent developments and prospects for unifying niche and neutral perspectives. Ecol Evol 4:2263-2277 . https://doi.org/10.1002/ece3.1092 
Mertl AL, Ryder Wilkie KT, Traniello JFA (2009) Impact of flooding on the species richness, density and composition of amazonian litter-nesting ants. Biotropica 41:633-641 . https://doi.org/10.1111/j.17447429.2009.00520.x

Ness JH, Bronstein JL, Andersen AN, Holland JN (2004) Ant body size predicts dispersal distance of antadapted seeds: Implications of small-ant invasions. Ecology 85:1244-1250 . https://doi.org/10.1890/030364

Nooten SS, Schultheiss P, Rowe RC, Facey SL, Cook JM (2019) Habitat complexity affects functional traits and diversity of ant assemblages in urban green spaces (Hymenoptera: Formicidae).

Myrmecological News 29:67-77 . https://doi.org/10.25849/myrmecol.news

Oksanen AJ, Blanchet FG, Friendly M, Kindt R, Legendre P, Mcglinn D, Minchin PR, Hara RBO, Simpson GL, Solymos P, Stevens MHH, Szoecs E (2020) Package 'vegan '

Oliveira PY De, Souza JLP de, Baccaro FB, Franklin E (2009) Ant species distribution along a topographic gradient in a "terra-firme " forest reserve in Central Amazonia. Pesq agropec bras 44:852-860 . https://doi.org/doi:10.1590/S0100-204X2009000800008

Oliveira U, Vasconcelos MF, Santos AJ (2017) Biogeography of Amazon birds: Rivers limit species composition, but not areas of endemism. Sci Rep 7:1-11 . https://doi.org/10.1038/s41598-017-03098-w

Pequeno PACL, Franklin E, Norton RA (2020) Determinants of intra-annual population dynamics in a tropical soil arthropod. Biotropica 52:129-138 . https://doi.org/10.1111/btp.12731

Pettorelli N, Vik JO, Mysterud A, Gaillard JM, Tucker CJ, Stenseth NC (2005) Using the satellite-derived NDVI to assess ecological responses to environmental change. Trends Ecol Evol 20:503-510 . https://doi.org/10.1016/j.tree.2005.05.011

Pringle EG, Santos TF dos, Gonçalves MS, Hawes JE, Peres CA, Baccaro FB (2019) Arboreal ant abundance tracks primary productivity in an Amazonian whitewater river system. Ecosphere 10: . https://doi.org/10.1002/ecs2.2902

Quesada CA, Lloyd J, Anderson LO, Fyllas NM, Schwarz M, Czimczik Cl (2011) Soils of Amazonia with particular reference to the RAINFOR sites. 1415-1440 . https://doi.org/10.5194/bg-8-1415-2011

Ramos CS, Isabel Bellocq M, Paris Cl, Filloy J (2018) Environmental drivers of ant species richness and composition across the Argentine Pampas grassland. Austral Ecol 43:424-434 .

https://doi.org/10.1111/aec.12579

Ribas CC, Aleixo A, Nogueira ACR, Miyaki CY, Cracraft J (2012) A palaeobiogeographic model for biotic diversification within Amazonia over the past three million years. Proc R Soc B Biol Sci 279:681-689 . https://doi.org/10.1098/rspb.2011.1120 
Ross KG, Gotzek D, Ascunce MS, Shoemaker DD (2010) Species delimitation: A case study in a problematic ant taxon. Syst Biol 59:162-184 . https://doi.org/10.1093/sysbio/syp089

Rosser N, Freitas AVL, Huertas B, Joron M, Lamas G, Mérot C, Simpson F, Willmott KR, Mallet J, Dasmahapatra KK (2019) Cryptic speciation associated with geographic and ecological divergence in two Amazonian Heliconius butterflies. Zool J Linn Soc 186:233-249 .

https://doi.org/10.1093/zoolinnean/zly046

Ruokolainen K, Moulatlet GM, Zuquim G, Hoorn C, Tuomisto H (2019) Geologically recent rearrangements in central Amazonian river network and their importance for the riverine barrier hypothesis. Front Biogeogr 11: . https://doi.org/10.21425/f5fbg45046

Sánchez-Restrepo AF, Chifflet L, Confalonieri VA, Tsutsui ND, Pesquero MA, Calcaterra LA (2020) A species delimitation approach to uncover cryptic species in the South American fire ant decapitating flies (Diptera: Phoridae: Pseudacteon). PLoS One 15:1-23 . https://doi.org/10.1371/journal.pone.0236086

Santorelli S, Magnusson WE, Deus CP (2018) Most species are not limited by an Amazonian river postulated to be a border between endemism areas. Sci Rep 8:1-8 . https://doi.org/10.1038/s41598-01820596-7

Shipley B (2016). Cause and correlation in biology: a user's guide to path analysis, structural equations and causal inference with R. 2 ed. Cambridge University Press, Cambridge

Silva SM, Townsend Peterson A, Carneiro L, Burlamaqui TCT, Ribas CC, Sousa-Neves T, Miranda LS, Fernandes AM, D'Horta FM, Araújo-Silva LE, Batista R, Bandeira CHMM, Dantas SM, Ferreira M, Martins DM, Oliveira J, Rocha TC, Sardelli CH, Thom G, Rêgo PS, Santos MP, Sequeira F, Vallinoto M, Aleixo A (2019) A dynamic continental moisture gradient drove Amazonian bird diversification. Sci Adv 5: . https://doi.org/10.1126/sciadv.aat5752

Souza JLP, Baccaro FB, Landeiro VL, Franklin E, Magnusson WE, Pequeno PACL, Fernandes IO (2016) Taxonomic sufficiency and indicator taxa reduce sampling costs and increase monitoring effectiveness for ants. Divers Distrib 22:111-122 . https://doi.org/10.1111/ddi.12371

Stéphane Dray A-BD and JT (2020) Package 'ade4.' https://doi.org/10.18637/jss.v022.i04>.License Tarli VD, Pequeno PACL, Franklin E, de Morais JW, Souza JLP, Oliveira AHC, Guilherme DR (2014) Multiple environmental controls on cockroach assemblage structure in a tropical rain forest. Biotropica 46: . https://doi.org/10.1111/btp.12138

Ter Steege H, Pitman NCA, Phillips OL, Chave J, Sabatier D, Duque A, Molino JF, Prévost MF, Spichiger R, Castellanos H, Von Hildebrand P, Vásquez R (2006) Continental-scale patterns of canopy tree composition and function across Amazonia. Nature 443:444-447 . https://doi.org/10.1038/nature05134 
Tuomisto H, Ruokolainen K, Yli-Halla M (2003) Dispersal, environment, and floristic variation of Western Amazonian forests. Science (80- ) 299:241-244 . https://doi.org/10.1126/science.1078037

Tuomisto H, Van doninck J, Ruokolainen K, Moulatlet GM, Figueiredo FOG, Sirén A, Cárdenas G, Lehtonen S, Zuquim G (2019) Discovering floristic and geoecological gradients across Amazonia. J Biogeogr 46:1734-1748 . https://doi.org/10.1111/jbi.13627

Vasconcelos HL, Vilhena JMS, Facure KG, Albernaz ALKM (2010) Patterns of ant species diversity and turnover across $2000 \mathrm{~km}$ of Amazonian floodplain forest. J Biogeogr 37:432-440 . https://doi.org/10.1111/j.1365-2699.2009.02230.x

Vellend M (2016) The Theory of Ecological Communities (MPB-57). Princeton University Press, Oxford Wallace AR (1854) On the Monkeys of the Amazon. Ann Mag Nat Hist 14:451-454 . https://doi.org/10.1080/037454809494374

Wang IJ., Bradburg GS (2014) Isolation by environment. Mol Ecol 23:5649-5662 . https://doi.org/10.1111/mec.12938

Wiescher PT, Pearce-Duvet JMC, Feener DH (2012) Assembling an ant community: Species functional traits reflect environmental filtering. Oecologia 169:1063-1074 . https://doi.org/10.1007/s00442-0122262-7

Yamane S (2013) A review of the ant fauna of the Krakatau Islands, Indonesia. Bull Kitakyushu Mus NatHist Hum Hist Ser A (Nat Hist) 11:1-66

Zuquim G, Tuomisto H, Jones MM, Prado J, Figueiredo FOG, Moulatlet GM, Costa FRC, Quesada CA, Emilio T (2014) Predicting environmental gradients with fern species composition in Brazilian Amazonia. J Veg Sci 25:1195-1207 . https://doi.org/10.1111/jvs.12174

\section{Figures}



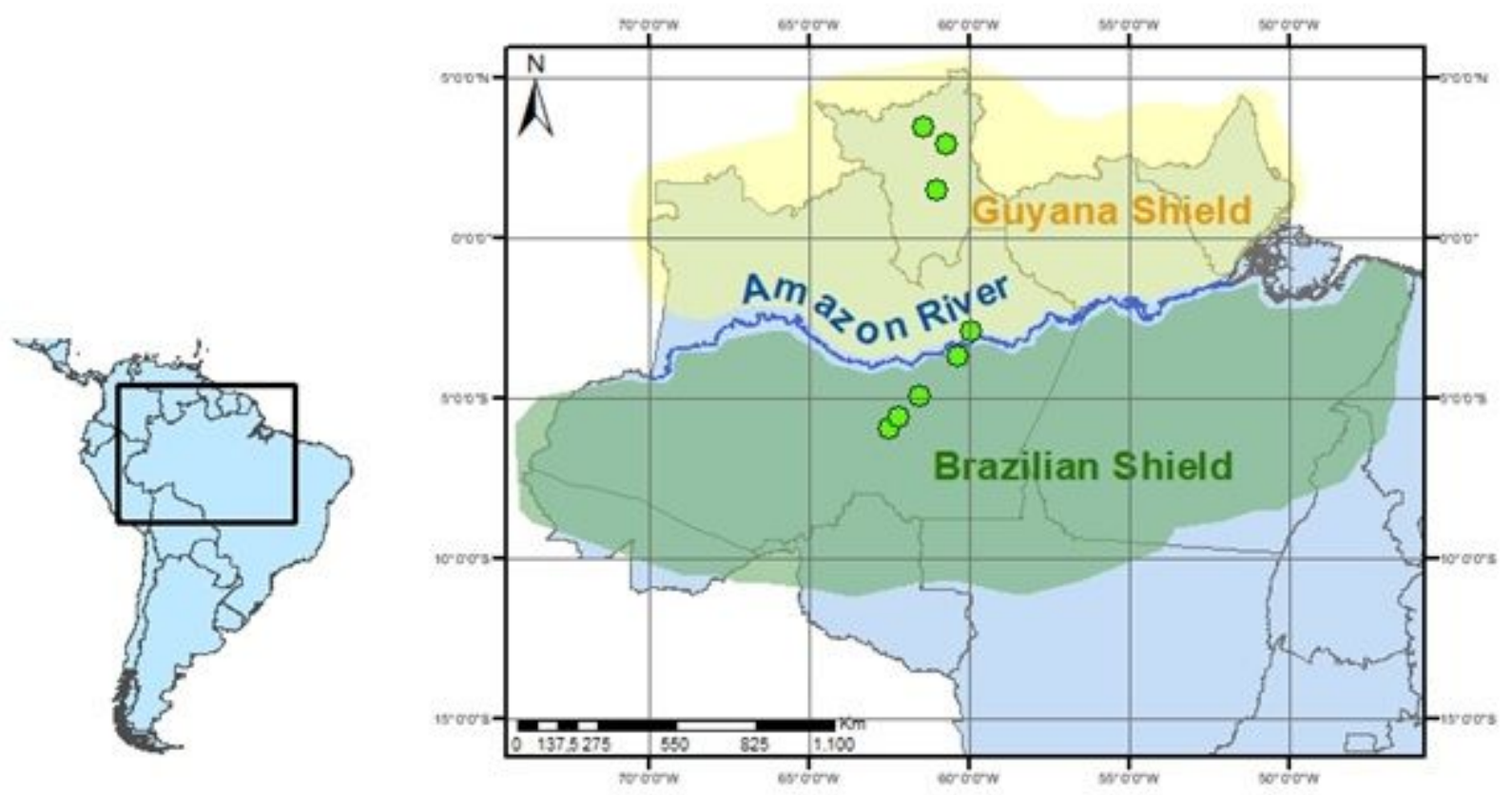

Figure 1

Map showing the location of collection points (green points) in the Brazilian Amazon Forest. The yellow colour shows the cover of Guyana Shield in Brazilian territory and green colour shows the cover of Brazilian Shield on map. The extension of the Amazon River along of study area it showed in blue transect.

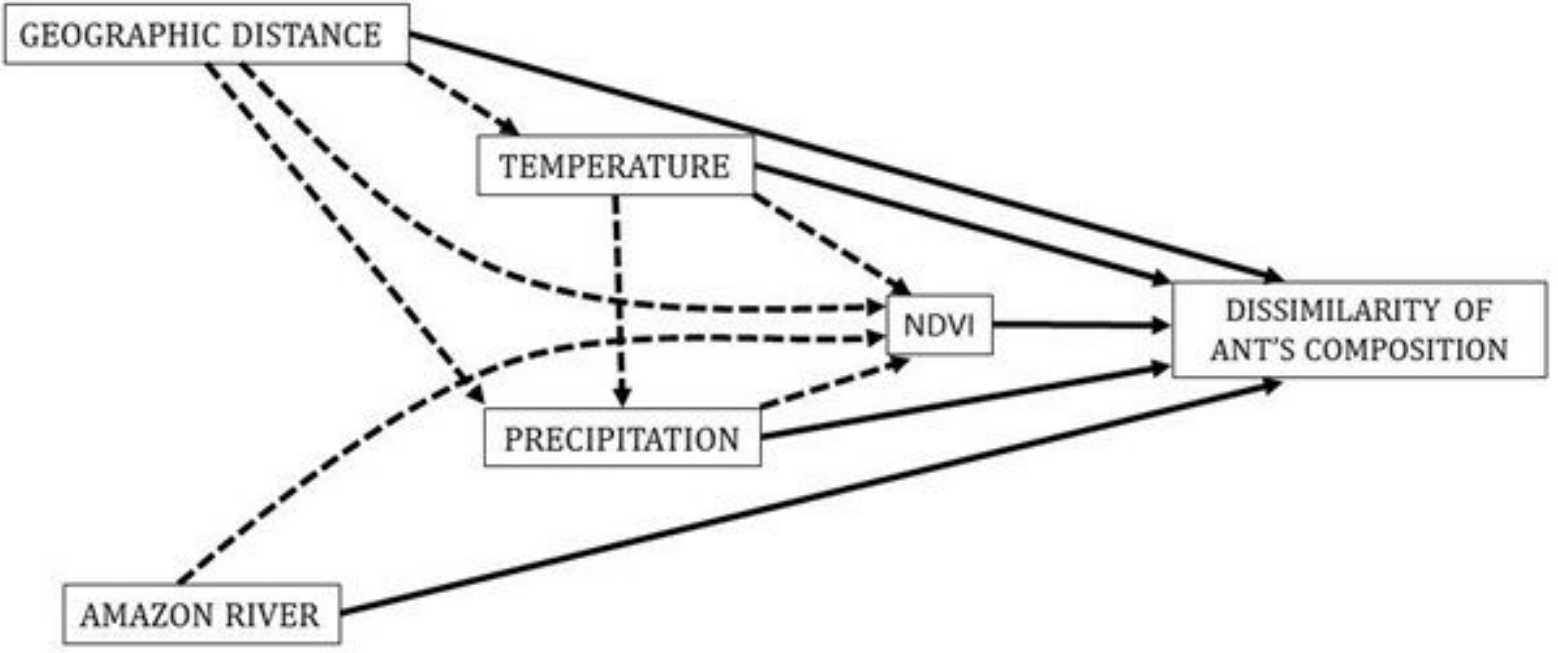

Figure 2 
Path diagram including the hypothesized direct and indirect effects of the variables. Dashed and solid arrows indicate the indirect and direct effects respectively.

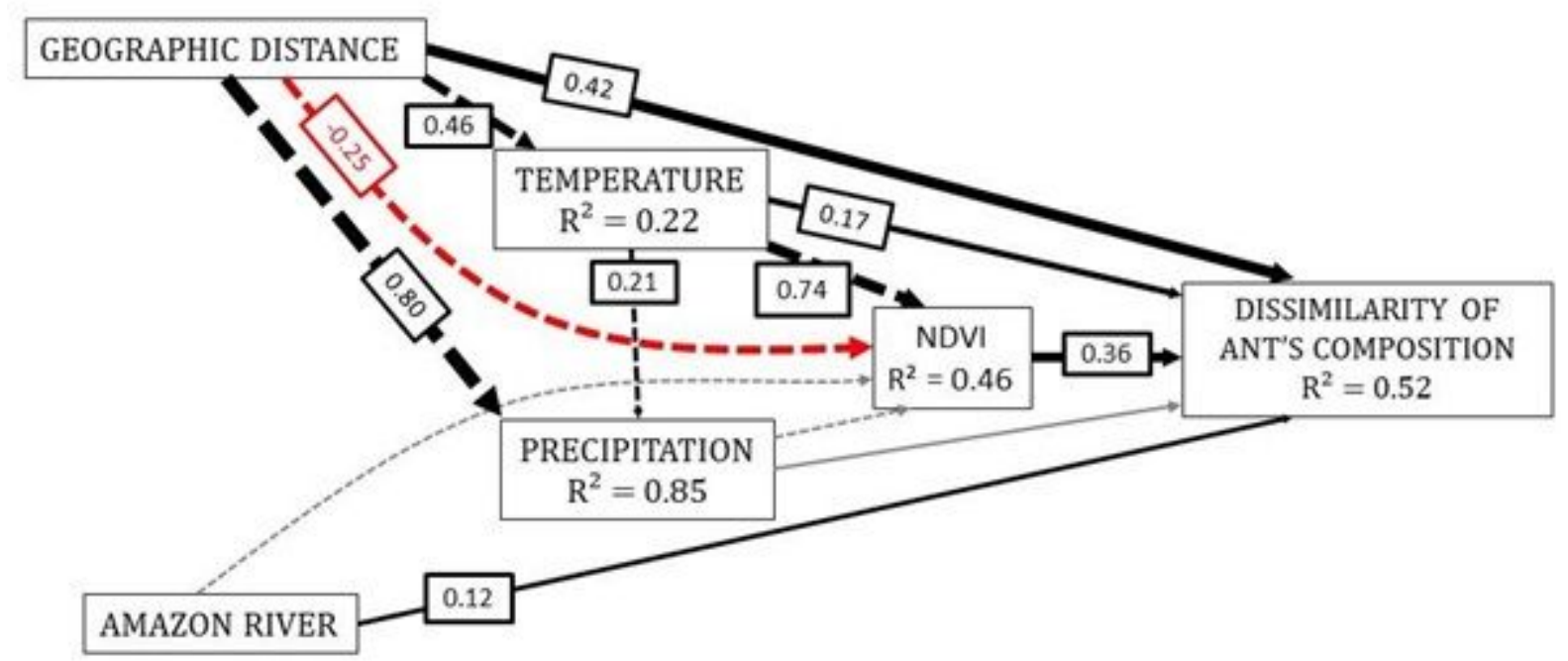

\section{Figure 3}

SEM results showing the direct and indirect effects of geography and environment on ant species dissimilarity across Central Amazonia. The $\mathrm{R}^{2}$ correspond to models described in Table 1. Black and red arrows represent positive and negative significant effects, respectively. Grey arrows represent nonsignificant effects Width is proportional to the magnitude of standardized coefficients. 

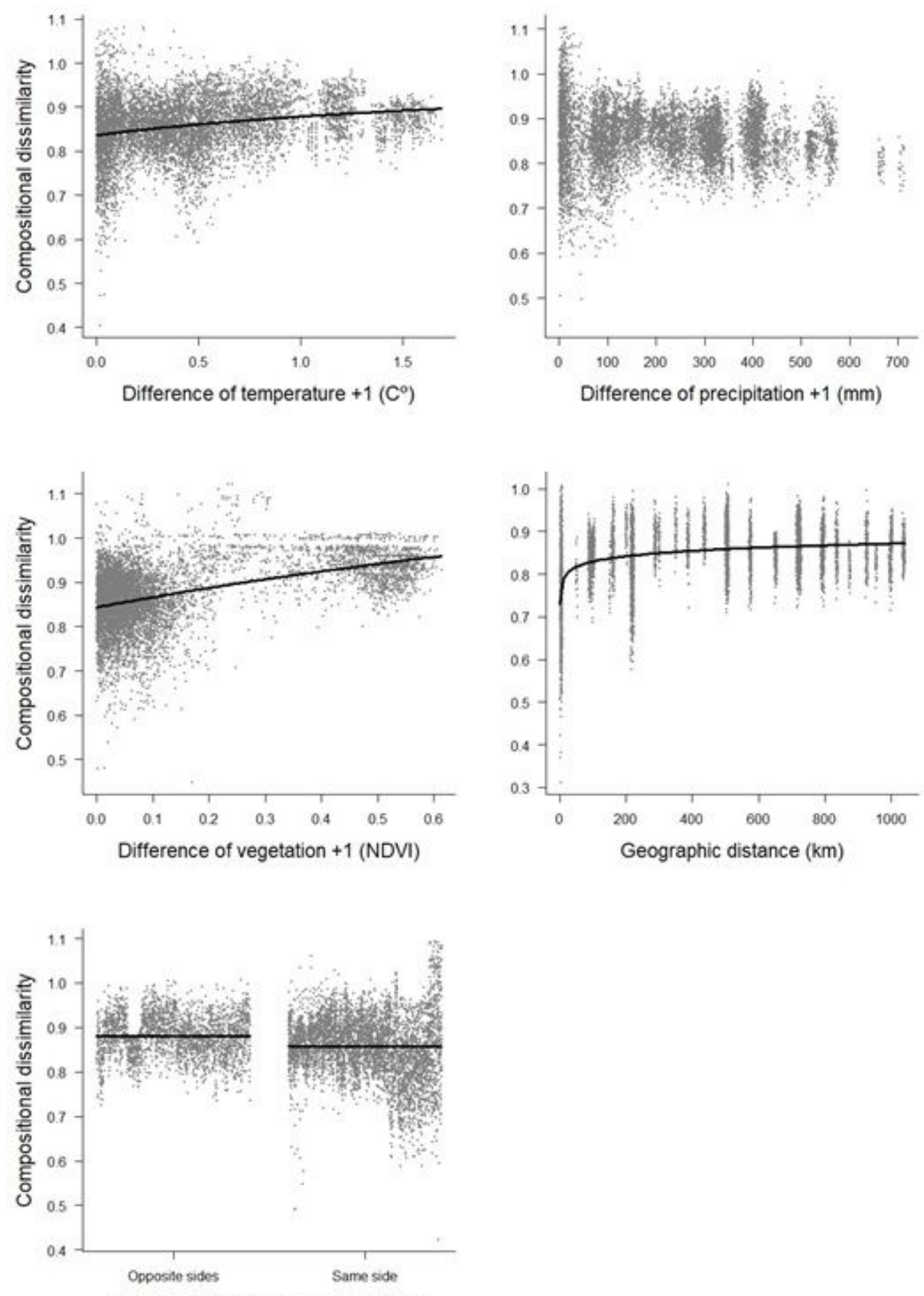

Regions separated by Amazon River

\section{Figure 4}

Partial regressions of ant compositional dissimilarity against direct predictors. The black line shows significant model fits. Each point is a comparison between a pair of plots. Vertical axes are partial residuals, so that plots show the expected effect of a variable when the other variables in the model are statistically held constant. 


\section{Supplementary Files}

This is a list of supplementary files associated with this preprint. Click to download.

- Suportinformation.docx 